\title{
DE VERSIONES Y AUTORES FICTICIOS EN EL QUIJOTE: A VUELTAS CON EL COMIENZO DE II, 44
}

\author{
JUAN C. LÓPEZ NIETO
}

Para Marina

1. Muy diversos han sido los pasajes del Quijote que la crítica ha ido considerando, a lo largo de los siglos, difíciles, ambiguos, equivocados o por completo faltos de sentido. Y si, por ejemplo, algunos (como el conocido "juicio paradójico" sobre el Tirante el Blanco y su autor que puede verse en I, 6 -que "solía considerarse «el pasaje más oscuro del Quijote»"-) parece que han sido finalmente aclarados, ${ }^{1}$ el principio del capítulo XLIV de la Segunda Parte de la obra magna de Cervantes sigue esperando un análisis adecuado, ya que presenta, a día de hoy, unos problemas aún no resueltos de forma satisfactoria, en mi opinión. En él puede leerse (modernizo tan solo la acentuación):

Dizen que en el propio original desta historia se lee, que llegando Cide Hamete a escriuir este capítulo no le traduxo su intérprete como él le auía escrito, que fue vn modo de quexa que tuuo el Moro de sí mismo, por auer tomado entre manos vna historia tan seca, y tan limitada, como esta de don Quixote, por parecerle que siempre auía

${ }^{1}$ Cf. E. C. Riley, Teoría de la novela en Cervantes, Madrid, Taurus, 1981, pp. $48-49$ y n. 2. 
de hablar dél y de Sancho, sin osar estenderse a otras digresiones, y episodios más graues, y más entretenidos. ${ }^{2}$

2.1. Como caso extremo, debe advertirse que a este pequeño locus cervantino se le ha solido negar el sentido, destacándose, de paso, el absurdo al que aboca. Fue la postura defendida por Diego Clemencín, para quien

Todo esto del principio del capítulo es una algarabía que no se entiende. Porque ¿cómo podía leerse en el propio original de la historia que no lo había traducido fielmente su intérprete? Ni ¿qué tiene que ver esto con la queja que tuvo el moro de sí mismo por haber tomado entre manos asunto tan seco y estéril? [...] Resulta de todo, que pudiera muy bien haberse excusado este largo y difuso preámbulo hasta donde vuelve a tomarse el hilo de la narración. ${ }^{3}$

Se iniciaba, así, una larga línea interpretativa del pasaje que destaca su total falta de significación, ${ }^{4}$ su oscuridad, ${ }^{5}$ la confusión que en él predomina, ${ }^{6}$ su

\footnotetext{
2 M. de Cervantes Saavedra, Segunda parte del Ingenioso caballero Don Quixote de la Mancha, Madrid, J. de la Cuesta para F. de Robles, 1615 [B. N. de Madrid, R / 32177], f. 164r. (Es el citado un pasaje que no presenta alteraciones significativas, por ejemplo, en las ediciones del siglo XVII del texto que se conservan en la Biblioteca Nacional de Madrid o en la de Valencia, P. P. Mey, 1616, de la RAE; y que, en las diversas impresiones de los siglos XVIII y XIX que consulto en la citada BN de Madrid, solo muestra tres erratas: "que fue à vn modo de quexa" [Madrid, 1723 y 1730]; "entendidos", por 'entretenidos' [Madrid, M. Martín, 1765]; y "siempre hablar" [Barcelona, Sierra i Marti, 1814]). En lo que sigue, sin embargo, se citará el Quijote por la edición de F. Rico (dir.), Don Quijote de la Mancha, 2 vols., Barcelona, Crítica, 1998.

${ }^{3}$ M. de Cervantes Saavedra, El ingenioso hidalgo don Quijote de La Mancha, ed. IV Centenario, Madrid, Ediciones Castilla, 1967 (que incluye las notas de Diego Clemencín), pp. 1765-66, n. 1. Aceptan, y citan, expresamente la opinión crítica de éste autores como J. J. Allen (M. de Cervantes, Don Quijote de la Mancha, II, Madrid, Cátedra, 1989, p. 349, n. 1) y F. Rico (ed. cit., I, p. 979, n. 1 y M. de Cervantes, Don Quijote de La Mancha, Barcelona, Círculo de Lectores/Galaxia Gutenberg, 2004, I, 1069, n. 1). En relación con ello, resulta sintomático, por ejemplo, que no tratara del pasaje J. Calderón (Cervantes vindicado en Ciento y quince pasajes del texto del Ingenioso hidalgo D. Quijote de la Mancha que no han entendido o han entendido mal algunos de sus comentadores o críticos, Madrid, 1854, pp. 213-217, §§ 94 y 95), que tanto corrige y lleva la contraria a D. Clemencín.

${ }^{4}$ Cf., por ejemplo, H. Percas de Ponseti (Cervantes y su concepto del arte, I, Madrid, Gredos, 1975, p. 163), J. B. Avalle-Arce (M. de Cervantes, Don Quijote de la Mancha, II, Madrid, Alhambra, 1979, p. 368, n. 1), C. Real Ramos ("Melisendra era Melisendra [La ficción en Cervantes]", en M. GARCíA MARTín et alii [eds.], Estado actual de los estudios sobre el Siglo de Oro. Actas del II Congreso Internacional de Hispanistas del Siglo de Oro, II, Salamanca, Universidad, 1993, [pp. 803-809], p. 806), F. Rico (M. de Cervantes, Don Quijote de La Mancha, Madrid, RAE-Alfaguara, 2004, cap. XLIV, n. 1) y S. Hutchinson, "Vacíos del ser y del saber en el «Quijote»", Rilce, 23, 1 (2007), 123-132, p. 129.

${ }^{5}$ Cf. E. C. Riley, op. cit., p. 196, así como, de nuevo, H. Percas de Ponseti, op. cit., I, 168.
} 
De versiones y autores ficticios en El Quijote: a vueltas con el ...

ambigüedad,7 el que resulta una broma mal entendida - que presenta "la perfecta imagen" de "una aporía o paradoja irreconciliable" acerca de la prioridad en el "binomio habla / escritura" -8 ...

2.2. A causa de esta aparente falta de sentido, algún estudioso ha intentado, incluso, modificar la lectura del fragmento para afinarlo y hacerlo correcto, coherente; es lo que llevó a cabo J. E. Hartzenbusch, quien, tratando de salir al paso de los reparos presentados por Clemencín con la corrección del propio texto del Quijote - que no es lo que escribió Cervantes, sin embargo (como ya advirtiera E. F. Rubens) 9 -, editó el comienzo de II, 44 como

Dicen que lo que en el propio original desta historia se lee, llegando Cide Hamete a escribir este capítulo, no lo tradujo su intérprete como él lo había escrito [...] (J. E. Hartzenbusch, El ingenioso hidalgo don Quijote de La Mancha, [VI], IV, Argamasilla de Alba, Manuel Rivadeneyra, 1863, p. 27).

$Y$, en nota, explicaba el editor los motivos de sus cambios -que le acabarían granjeando algunas críticas ya en su propia época ${ }^{10}$ :

Sabido es que el autor y el traductor del Quijote son en realidad una misma persona; pero fingiendo que fueron dos, ocurre pensar que si en el original de Cide Hamete pudo escribir el traductor lo que le pareciera, no sería cuando llegaba Cide Hamete a escribir el capítulo. Se ha variado por eso levemente la cláusula, para darle un sentido que no repugne, como haría Cervantes (J. E. Hartzenbusch, ed. cit., [VI], IV, p. 305, n. 20).

Todavía algo más tarde, el propio Hartzenbusch se empeñaba en nuevas interpretaciones del pasaje, en buena medida innecesarias, en mi opinión (v. i.):

Aceptada la ficción de que hay un autor arábigo de este libro, un traductor al castellano y un editor, parece no se debía decir que, llegando el

\footnotetext{
${ }^{6}$ Cf. S. Fernández Mosquera, "Los autores ficticios del «Quijote»", AC, XXIV (1986), 47-65, p. 60; véase, además, J. M. ${ }^{a}$ Paz Gago, "El Quijote: narratología", Anthropos, 100 (1989), 43-48, p. 46a.

7 Cf. M. de Cervantes, El ingenioso hidalgo don Quijote de La Mancha, ed. V. Gaos (con adiciones de Alberto del Campo), II, Madrid, Gredos, 1987, p. 599, n. a 4.

8 J. A. Parr, "La paradoja del Quijote", en Actas del III Coloquio Internacional de la Asociación de Cervantistas (Alcalá de Henares, 12-16 nov. 1990), Barcelona, Anthropos, 1993, [pp. 43-56], p. 54.

9 "Cide Hamete Benengeli, autor del «Quijote»", Comunicaciones de Literatura Española, I, 1-3 (1972), 8-13, p. 12, n. 1. Incluso, en una edición del Quijote II de Barcelona, Tomás Gorchs, 1859 (BN de Madrid, R/23883) se conservan correcciones autógrafas de Hartzenbusch, entre otras, al pasaje de supra (p. 269) -y que ni lo reordenan sintáctica y lógicamente ni lo aclaran-.

${ }^{10}$ Cf. R. Benítez, Cervantes en Galdós, Murcia, Universidad, 1990, pp. 27-28. Véase sin embargo, para cuestiones conexas a este hecho, F. Rico, El texto del «Quijote», Barcelona, Destino, 2005, pp. 28-32.
} 
autor a escribir el capítulo, el traductor no siguió fielmente al autor. El traductor no traduciría al tiempo que escribía originalmente el autor; pero como en realidad Cide Hamete y Cervantes son la misma persona, puede considerarse ésta como una chanza, en cuyo caso no es necesario advertir que el gerundio llegando equivaldría al compuesto habiendo llegado (Las 1633 notas [...] a [...] 'El ingenioso hidalgo', Barcelona, 1874, p. 153b, n. 1360).

2.3. No han faltado, sin embargo, críticos y editores que han tratado de comprender de forma más positiva el sentido último del inicio de II, 44 (o mejor, y tan sólo, de su primera parte [v. i.]), aunque el resultado final de su trabajo y de sus hipótesis ha sido, a mi juicio, poco clarificador también. Y, así, debe recordarse cómo, para el P. Rufo Mendizábal, el "intérprete" que se menciona al principio de II, 44 se refiere a un 'traductor' que el moro Cide Hamete habría contratado o "tendría" para verter a la lengua arábiga "la historia o los documentos de don Quijote escritos en español":

Queriendo explicar Cide Hamete por qué en la primera parte del Quijote había insertado algunas novelas sueltas y no en la segunda, llegando a este capítulo [XLIV] dijo que se apartó de lo que su intérprete (siendo Cide Hamete historiador arábigo, tendría alguno que le interpretase la historia o los documentos de don Quijote escritos en español) le había traducido, por parecerle seca y limitada la historia de solas dos personas [...] (M. de Cervantes Saavedra, El ingenioso hidalgo don Quijote de La Mancha, Madrid, Ediciones "Fax", 1945, p. 935, n. 1.).

Por el contrario, E. Cros - que se ocupa en su trabajo, en exclusiva, del párrafo inicial de II, 44- supuso la presencia e intervención de un 'cuarto' personaje anónimo, que, sumado a Cide Hamete, al traductor morisco y al 'segundo autor'-editor de la traducción como un mediador más entre los hechos narrados y el lector, "[...] aurait relu la traduction en la comparant avec l'original et en consignant en marge ses observations", entendiendo, para "rétablir la logique de ce passage",

[...] par el propio original, l'original espagnol, par distinction d'une part avec l'original arabe et, d'autre part, avec le texte définitif qui, lui, doit tenir compte, selon toute vraisemblance, des annotations marginales du commentateur anonyme ("Miguel de Cervantes. Don Quijote de la Mancha", en S. Saillard et alii, Introduction à l'étude critique. Textes espagnols, Paris, Libr. Armand Colin, 1972, pp. 230-243; p. 233). ${ }^{11}$

11 Se trataría, para él, de "un troisième texte qui correspond à la traduction commentée" que, y en ello sí que estoy de acuerdo, "Cervantes nous fait imaginer (pour la première et pour la dernière fois à notre connaisance)" (p. 234). El motivo de este juego literario para E. Cros es claro: "Plus 
De versiones y autores ficticios en El Quijote: a vueltas con el ...

En el caso de E. F. Rubens, se presenta, primero, una paráfrasis explicativa del fragmento que aquí me ocupa:

Alguien (un narrador) refiere que Cide Hamete escribió el capítulo, quejándose del trabajo de escribir la historia [...] de D. Quijote; y que el traductor no le tradujo como Cide Hamete "le había escrito" [...] El traductor no acepta [...] que Cide Hamete se queje, por ser partidario de "la historia tan seca y tan limitada". Cide Hamete, contra su opinión, como agrega más adelante, "se contiene y cierra en los estrechos límites de la narración". De la queja de Cide Hamete no se nos da el texto, que no es traducido, por no estar de acuerdo el traductor. Es lo que "dicen", no con las palabras mismas de Cide Hamete ni del traductor, sino del narrador. Hay gente que ha leído el original, antes de la intervención del traductor y del narrador (op. cit., p. 8);

y, más tarde, se concluye cómo, al comienzo del pasaje,

el objeto de Cervantes fue - posiblemente- alertar al lector sobre un exceso de racionalización en el tratamiento de los personajes de la historia de la novela, para que, de ese modo, se aproximen a los de la historia que refieren (ibid., p. 12, n. 1).

F. W. Locke, ${ }^{12}$ por otro lado, afirmó -en una metafísica meditación sobre el texto-13 que en el fragmento citado supra se hacía referencia, en último término, al "autor original" de la obra - esto es, Miguel de Cervantes, que componía y creaba de la nada casi a imitación de Dios-, por completo previo (por creador y supervisor de la novela) a la versión árabe de la historia de don Quijote supuestamente realizada por Cide Hamete; ${ }^{14}$ de ahí que pudiera saber

que la pirouette malicieuse de Cervantes c'est cette recherche de l'ambiguïté ainsi que ces variations de distance qui retiendront notre attention" (ibid.). Véase ahora una elucubración similar, como "Otra posibilidad" de su explicación del pasaje, en S. Hutchinson, op. cit., p. 129.

12 "El sabio encantador: The Author of Don Quixote", Symposium, XXIII, 1 (1969), 46-61, pp. 54-58.

${ }^{13}$ Cf. J. A. Parr, "Don Quixote»: An Anatomy of Subversive Discourse, Newark, Del., Juan de la Cuesta, 1988, p. 60.

${ }^{14}$ Cf. F. W. Locke, op. cit., pp. 58-60. "The obvious fact is that Don Quixote does not really know who is writing his life. For him it is not Benengeli, but as he keeps insisting algún sabio encantador, someone misterious and whom I have identified with the autor original of II.44" (ibid., p. 58); "In the proprio original all is known, the entire atemporal scope of Don Quixote. This, of course, is the reason why that original version can know what is to happen before it transpires. Cervantes imitates the creative power of God in that he not only brings his creation into existence but sustains it from moment to moment by his "creative act»" (ibid., p. 59). 
(y decir) que, tiempo después, el intérprete morisco de esta última no traduciría fielmente lo escrito por el cronista e historiador moro. ${ }^{15}$

Por su parte, H. Mancing entendió que el inicio de II, 44, junto con el lamento del supuesto autor por las restricciones que le imponía el material que había elegido, presentaba un tipo de "ironic narrative device": "a brilliantly paradoxical reductio ad absurdum in the process of ridiculing the narrative structure of Don Quijote" (además de su credibilidad); y es que, según él,

That Cervantes the editor, who theoretically has the manuscript before him as he writes, should have to rely on hearsay evidence [...] in order to report that, while composing this chapter, Cide Hamete wrote that his translator mistranslated it; that Cervantes would not consult with the translator, presumably working with him all the while, in order to correct possible errors; or that the editor and/or translator would not either affirm or deny the validity of Cide Hamete's complaint, all combine to destroy any shred of truthfulness, reliability or historicity remaining in the presentation of the story (The Chivalric World of Don Quijote, Columbia \& London, University of Missouri Press, 1982, pp. 205-206).

En línea con E. Cros (v.s.), A. del Campo postulaba la existencia de una anotación en el propio original de la Historia de Cide Hamete -aunque insertada en el manuscrito, en su opinión, por el traductor morisco- para dotar de pleno sentido a lo que, si no, le parecía que no lo tenía en modo alguno:

Algo podría explicarse, a mi juicio, suponiendo que el mismo traductor dejó en el original de esta historia una anotación marginal en la que reconocía no haber trasladado como estaban las palabras de Cide Hamete, sino poniéndolas en estilo indirecto. [Es lo que casi sucede en] el principio de II, 24, donde es el propio Cide el que inserta una nota marginal (add. a V. Gaos, ed. cit., II, p. 599, n. a 4]).

Algo más tarde, J. G. Weiger16 interpretaba el oscuro comienzo de II, 44 como el resultado de una información dada al narrador del texto cervantino por unos anónimos lectores del original árabe de la Historia escrita por Cide Hamete. Y, como estos le advertirían de la mala traducción del pasaje realizada por el morisco aljamiado, el narrador puede dar cuenta del hecho a sus lectores en el inicio del pasaje, al tiempo que resumía lo que el morisco no había acabado

15 "Perhaps we can now see that the 'contradictions' in the mirroring of narrators that Cervantes presents us with are not at all contradictions but an essential part of the central metaphor of Don Quixote" (ibid., p. 60).

16 In the margins of Cervantes, Hanover \& London, University of Vermont by University Press of New England, 1988, pp. 18-19. 
De versiones y autores ficticios en El Quijote: a vueltas con el ...

de traducir. ${ }^{17}$ De ello debe deducirse por tanto, según Weiger, que "The text's instability becomes increasingly evident" (op. cit., p. 19).

Asimismo, ha de recordarse cómo para J. A. Parr (op. cit. en n. 13, pp. 60$61)$, inicialmente, el comienzo de II, 44 "seems to transgress logic, rethoric and decorum simultaneously", lo que acaba entendiendo, al igual que el recurso a los 'autores ficticios' y su "[...] search of unimpeachable authority", como "a parody of the quest for certainity"; por ello, en el fragmento advierte el uso de una autoridad (creador de una versión, la "original", anterior a la de Cide Hamete) de existencia conocida por el segundo autor-narrador de la novela 'de oídas' y que constituiría una fidedigna autoridad ("an ever evanescent authority") de la narración de los hechos. Más tarde, sin embargo, entenderá el fragmento como "el ejemplo más llamativo" en el Quijote de "oralidad encajada en la escritura" para "parodiar la búsqueda de las fuentes", "del centro o de los orígenes" -ya fueran históricos, ya "prístinos" (por parte del protagonista)-, tan cara a la época;18 esto es, como "un comentario irónico" -y "liberador de ilusiones falsas" - sobre la búsqueda incesante de "orígenes y precedentes" —que resulta "tan inútil e ilusoria como la búsqueda de la edad de oro"—19.

Finalmente, en este rápido repaso de diversas opiniones sobre el sentido del inicio de II, 44, puede señalarse cómo C. Real Ramos (op. cit., II, p. 807), a pesar de citar a D. Clemencín y afirmar lo "llamativo", "extraordinario" e "incongruente" del mismo (v. s.), avanza una explicación que recuerda, en buena parte, la postura defendida por F. Locke - si bien que destacando la figura del narrador (en vez de la del autor, al que el citado Locke alude) y la función, junto con otros elementos de muy diverso carácter, ${ }^{20}$ de "ponernos de manifiesto la ficcionalidad del texto" que desempeña en la obra-:

Pero es que el narrador no sólo es omnisciente respecto a sus personajes, sino que además es un perfecto conocedor del texto, haciendo frecuentes referencias prolépticas $\mathrm{o}$ anticipatorias y paralépticas $\mathrm{o}$

\footnotetext{
17 Cf. J. M. Martín Morán (El Quijote en ciernes, Torino, Edizioni dell'Orso, 1990, pp. 156-57), para quien, a causa del "recuerdo popular de los escritos de Cide Hamete" propio de la Segunda Parte -frente al recuerdo oral de "las hazañas de don Quijote" que era peculiar de la I Parte-, "incluso se discute alguna solución del traductor" (p. 157); "La forma impersonal «dicen» hace pensar en un conocimiento directo del relato de Cide Hamete por parte de alguien desconocido que no comparte la versión del morisco" (ibid.).

18 J. A. Parr, op. cit. en n. 8, pp. 52 y 53; cf. pp. 48 y 53: “Reconsiderando el pasaje [...] me parece que el aspecto esencial tiene que ver más bien con la búsqueda del centro o de los orígenes".

19 Ibid., p. 54.

20 Así, por ejemplo, "El juego de los narradores, las imprecisiones y contradicciones del narrador omnisciente, esas metalepsis o transgresiones narrativas en las que el personaje habla del autor, en que los personajes fictivos reconocen a nuestros héroes como los personajes reales de una historia de ficción, etc." (C. Real Ramos, op. cit., II, pp. 808-9).
} 
retrospectivas, cambiando de focalización, de punto de vista, con continuas referencias directas al autor (cf. ibid., pp. 804, 807 y 809).

3. A pesar de todo lo anterior, y tal como advirtiera E. C. Riley (op. cit., p. 20) a propósito del posible origen de las teorías literarias de Cervantes, parece que "desde un principio se han dado por sentadas demasiadas cosas" también en el caso que me ocupa (por inducción de lo señalado por D. Clemencín, seguramente). ${ }^{21}$ Es lo que ocurre con las afirmaciones acerca de la falta de sentido del pasaje que se han podido ver supra; con la idea, explícita o implícita en muchos de los autores que se han ocupado del fragmento, de que una lectura literal del mismo no era válida ni parcialmente; o con la casi general convicción -con algunas excepciones, algunas de ellas supra destacadas- de que el "intérprete" al que se alude al comienzo de II, 44 no es otro que el "traductor morisco aljamiado' de I, 9 (al que el 'segundo autor' de la novela y primer editor ficticio de la misma encargara la traducción de la Historia de don Quijote de La Mancha, de Cide Hamete Benengeli, que había encontrado en el Alcaná de Toledo) ${ }^{22}$, a pesar de que ello resulta a todas luces imposible e incongruente.

4. Así las cosas, y ante las distintas interpretaciones del pasaje, las dudas que despierta o, simplemente, las numerosas protestas de falta de sentido que sobre él se han vertido, quizá lo más prudente sea volver a ocuparse del texto citado al principio (pues volver al texto es siempre la mejor manera de empezar

${ }^{21}$ Cf., por ejemplo, A. Martín Jiménez, Cervantes y Pasamonte. La réplica cervantina al «Quijote» de Avellaneda, Madrid, Biblioteca Nueva, 2005, p. 262.

22 Es esa la opinión de D. Clemencín (loc. cit.), J. E. Hartzenbusch (loc. cit.), C. Sabor de Cortázar e I. Lerner (M. de Cervantes Saavedra, El ingenioso hidalgo don Quijote de La Mancha, Buenos Aires, Eudeba, 22005, p. 743, n.), G. Haley ("El narrador en Don Quijote: el retablo de Maese Pedro", en El Quijote de Cervantes, Madrid, Taurus, 1984, [pp. 269-287], p. 284), F. W. Locke (op. cit., pp. 53 y 54), E. Cros (op. cit., pp. 233), E. F. Rubens (op. cit., p. 8), M. Socrate (Prologhi al «Don Chisciotte», Venezia-Padova, Marsilio Ed., 1974, p. 38), R. S. El Saffar ("La [f] unción del narrador ficticio en Don Quijote", en G. Haley, op. cit., [pp. 288-299], pp. 99 y 123), H. Percas de Ponseti (op. cit., I, pp. 93-95, 163, 175 y 178), F. de Toro ("Don Quijote como «deconstrucción» de modelos narrativos", en M. Criado de Val [ed.], Cervantes, su obra y su mundo. Actas del I Congreso Internacional sobre Cervantes, Madrid, Edi-6, 1981, [pp. 635-651], p. 641), H. Mancing (op. cit., p. 206), R. M. Flores ("The rôle of Cide Hamete in Don Quixote", BHS, LIX, [1982], 3-14, p. 9), Á. Basanta (Don Quijote de la Mancha, II, Barcelona, Plaza \& Janés, 1985, p. 1089, n. 2 y El ingenioso hidalgo Don Quijote de la Mancha, Madrid, Anaya, 2005, p. 1270, n. 1), S. Fernández Mosquera (op. cit., p. 60), A. del Campo (add. a V. Gaos, op. cit., II, p. 599, n. a 4), J. G. Weiger (op. cit., pp. 18-19), J. M. ${ }^{a}$ Paz Gago (op. cit., p. 46a), M. Molho ("Instancias narradoras en Don Quijote", MLN, 104, 2 [1989], 273-285, p. 281), J. A. Parr (op. cit. en n. 8, p. 54), J. M. Martín Morán (op. cit., pp. 154, 157 y 195), F. Rico (op. cit. en n. 2, I, p. 979, n. 1), A. Martín Jiménez (El «Quijote» de Cervantes y el «Quijote» de Pasamonte, una imitación recíproca, Alcalá de Henares, CEC, 2001, pp. 344-45), A. Rey Hazas (Don Quijote de la Mancha, Zaragoza, Edelvives, 2005, p. 744, n. 1), S. Hutchinson, op. cit., p. 129... 
De versiones y autores ficticios en El Quijote: a vueltas con el ...

a tratar de entenderlo cuando presenta alguna dificultad), aunque teniendo en cuenta algunas aportaciones de quienes se han ocupado del fragmento arriba citado que considero por completo acertadas y útiles para su aclaración. ${ }^{23}$

Debe advertirse por tanto, en primer lugar, que, como señalara E. Cros, la labor del fingido autor árabe - que queda claro en I, 9 que se realiza "dans le passé" respecto del posterior trabajo del traductor aljamiado morisco y el segundo narrador- y la de su supuesto «intérprete» parecen estar y producirse de forma muy cercana en el tiempo (y quizá, incluso, en estrecho contacto):

[...] la construction de la phrase incriminée (llegando Cide Hamete a escribir este capitulo, no le tradujo su intérprete como él le había escrito) suggère [...] la simultanéité des deux actions (la création et la traduction) ou, du moins, suggére-t-elle que la traduction suit inmédiatement la création (op. cit., 233; cf. p. 234). ${ }^{24}$

Junto a lo anterior, hay que tener presente que el pasaje - una más de las digresiones relacionadas con Benengeli con las que inicia o cierra Cervantes algunos capítulos del Quijote de 1615 (v. i.) - surge, como ha destacado la crítica, de su "complejo perspectivismo narrativo", su "juego de perspectivas", 25 de la multiplicidad de los puntos de vista conseguidos en la obra con esos “ «poliedros perspectivísticos»: Anales de la Mancha, Cide Hamete, traductor, voces anónimas, sabios encantadores, la publicación de la novela, etc. [que componen su "esencia"]" $26 \mathrm{y}$, muy especialmente, con el juego de 'autores ficticios' creado por el alcalaíno en la obra (esa estructura en "escalerilla de los narradores" ficticios que se menciona en F. Rico [ed. cit. en n. 2, II, p. 580, n. a 979.1] y con la que se parodiaban "las tendencias pseudohistóricas de los autores de las novelas de caballerías" 27 al tiempo que se presentaban múltiples "puntos de vista refractados y superpuestos [para] hacer continuos contrastes

\footnotetext{
${ }^{23}$ Véase supra n. 2. Los lectores apresurados -o prudentes- pueden pasar directamente a leer la interpretación del comienzo de II,44 que propongo en \$§ 5-6 de infra, saltándose así, si ese es su gusto, las diversas reflexiones, análisis y comentarios que de inmediato siguen (y que, como es lógico, tratan de ilustrarla al tiempo que explican algunos de los aspectos a ella concernientes).

${ }^{24}$ Cf. J. G. Weiger, op. cit., p. 18: "If we are to take the sentence literally, the translator performed his function as Cide Hamete was writing the original [...]"; "[...] in II, 44 we are forced to envisage the translator as waiting for Cide Hamete to finish writing. Or so they say".

25 Á. Basanta, ed. cit. de 1985, II, p. 1089, nn. 1 y 2; cf., por ejemplo, J. B. Avalle-Arce (ed. cit., II, p. 368 , n. 1) - que destaca, en la novela, la "forma chusca de problematizar" esta cuestión-, J. J. Allen (ed. cit., II, p. 349, n. 1) y F. Martínez-Bonati (El «Quijote» y la poética de la novela, Alcalá de Henares, CEC, 1995, p. 94).

${ }^{26}$ M. de Cervantes Saavedra, Don Quijote: $2^{a}$ Parte, ed. F. Sevilla Arroyo-A. Rey Hazas, Alcalá de Henares, CEC, 1993, p. 886, n. 1.

27 L. Spitzer, Lingüística e Historia literaria, Madrid, Gredos, 1968, p. 143.
} 
retóricos", 28 que acaban socavando la autoridad narrativa y obligan al lector a analizar críticamente lo que se le narraba).

Con todo, debe notarse cómo la esencia de ese juego de 'autores ficticios' y de planos narrativos (también ficticios) creados por Cervantes en el Quijote -a partir de un sistema autorial que le permitía, al mismo tiempo, mantener la distancia respecto de sus personajes y el mando de su historia ${ }^{29}$ (y en el que, no se olvide, cada intermediario es, a su vez, "lector crítico de una versión previa [...]" [G. Haley, op. cit., p. 272]) - varía en 1615 respecto de lo creado en 1605 - por lo que acaba resultando la Segunda Parte, en realidad, "una novela diferente" del Quijote I-30. De ahí que considere que no está de más recordar cómo en la Primera parte de la novela se puede atisbar, al menos, hasta un total de ocho (tipos de) 'autores' ficticios y/o versiones de los mismos:

\section{[-Supuestos hechos de don Quijote (y Sancho)]}

-1 . Los distintos autores, verdaderos o no, que se ocupan inicialmente de la historia de don Quijote (I, 1-2 [sobre todo, pp. 43 y 48]) ${ }^{31}$

-2. Versión del «primer autor», anónima y muy burlona (Quijote I, 18); es obra de "an unspecified narrator" (Riley, op. cit. en n. 29, p. 808) que resulta, además, "un investigador que intenta reunir [y acoplar] todo el material a su alcance, sea en otras versiones escritas o en los anales de la Mancha" (J. A. Parr, op. cit. en n. 8, p. 48); será, finalmente, 'una voz descartada" 32 que "Se desvanece y [de la que] no volvemos a saber [cosa

\footnotetext{
${ }^{28}$ M. Gerli, "Estilo, perspectiva y realidad: Don Quijote, I, 8-9", en M. Criado de Val (ed.), op. cit., [pp. 629-634], p. 630. Debe advertirse sin embargo, de acuerdo con F. Martínez-Bonati (op. cit., p. 108), que los distintos autores ficticios que conforman el complejo esquema autorial del Quijote "constituyen un recurso esencialmente argumental y estilístico" en manos del "narrador -y, en última instancia [...] el autor-" y que no son más que "versiones ficticias del autor empírico, del responsable del acto de escribir, pero no del responsable del acto de narrar" -quien "no participa" en la historia y "narra desde un nivel superior y exterior" a la misma- (J. M. ${ }^{a}$ Paz Gago, op. cit., pp. 44a y 45a; cf. asimismo, por ejemplo, F. Rico, op. cit. en n. 10, p. 444).

${ }_{29}$ Cf. R. S. El Saffar (op. cit., p. 299) y J. M. ${ }^{a}$ Paz Gago (op. cit.). Se trata de "[...] the other intermediaries and incidental sources of information, of which in fact there are quite a number" de que hablara E. C. Riley, "Three versions of don Quixote", MLR, 68 (1973), 807-819, p. 816.

30 Cf. por ejemplo, respectivamente, J. M. Martín Morán (op. cit., p. 147) y E. C. Riley (Introducción al «Quijote», Barcelona, Crítica, 2004, p. 121), así como F. Rico, op. cit. en n. 10, pp. 317, n. 36, y 324.

31 "que en esto hay alguna diferencia en los autores que deste caso escriben [...]" (I, 1 [p. 37]); "los autores desta tan verdadera historia", frente a "otros" (I, 1 [p. 43]); "Autores hay que dicen [...] otros dicen [...]" (I, 2 [p. 48])... Véase ahora también, en relación con lo que sigue, J. Á. Ascunce, “Autoría y manuscritos del «Quijote» en el "Quijote»", Rilce, 23, 1 (2007), 41-59.

32 G. Haley, "The Narrator in Don Quixote: A discarded Voice", en Estudios en honor a Ricardo Gullón, Lincoln, Nebr., University, 1984, pp. 173-185.
} 
De versiones y autores ficticios en El Quijote: a vueltas con el ...

alguna]"33 ya que el segundo narrador "no halló más escrito destas hazañas de don Quijote [compuestas por aquel] de las que deja referidas" en I, 1-8 (Quijote, I, 8 [p. 104]). ${ }^{34} \mathrm{Al}$ parecer, todo lo que conoce de la historia de don Quijote lo ha encontrado escrito en fuentes o textosbase anteriores ( $c f$. Haley, op. cit. en n. 32, p. 181), aunque no es demasiado crítico ni riguroso con ellos (ibid., pp. 181-82); por esta causa, resulta "an unreliable ['infidente'] narrator" que trata su materia como si fuera más un novelista que un historiador (ibid., p. 183).

-3. Versión árabe original de la Historia de don Quijote de la Mancha de Cide Hamete Benengeli (caps. I, 9, 15, 16, 22, 27 e inicio de 28), historiador presentado, a un tiempo, como verídico y como "mendaz" $-\mathrm{y}$, por tanto, poco fiable (como su versión de los hechos [ $c f$. Riley, op. cit. en n. 30, p. 200)])-, por "moro", por poco objetivo (cf. M. Gerli, op. cit., p. 633]) y por ser "un espíritu creativo propenso a una escritura sin control" (El Saffar, op. cit., p. 290]). De él se sabe muy poco, como es bien sabido, y su voz (que nunca se escucha, a no ser desde el margen) "es siempre filtrada por el traductor o la voz editorial" y "marginada" por el 'supernarrador' intuido al final de I, $8-0$, sin más, por el propio autor(J. A. Parr, op. cit. en n. 8, pp. 49 y 51]); como advierte Percas de Ponseti (op. cit., I, 98-99), "casi no sabemos nada cierto de [Cide Hamete] excepto que es prolijo [...] tal vez algo descuidado por andar cambiando los nombres [y] no es tan puntual como se ha dicho repetidas veces [...]". Está aparentemente cerca de los hechos e, incluso, resulta "algo pariente" del arriero relacionado con Maritornes en I, 16 (p. 171), aunque, finalmente, no sea más que "un personaje marginado, pasivo,

\footnotetext{
33 J. A. Parr, "Las voces del Quijote y la subversión de la autoridad", en A. D. Kossoff et alii (eds.), Actas del VIII Congreso de la AIH (22-27 agosto 1983), II, Madrid, Istmo, 1986, [pp. 401-408], p. 402.

34 A causa de esto último, no parece posible que la versión inicial de los hechos de don Quijote fuera obra de Cide Hamete Benengeli -o que se tradujera de su original árabe-, como sería lo lógico y coherente en la obra (pues, si no, ¿cómo es posible que se encuentre un texto en árabe que continúe y rellene perfectamente la laguna presentada en un texto escrito en castellano?) y defienden, por ejemplo, C. Neupalsingh ("La aventura de los narradores del Quijote", en A. M. Gordon y E. Rugg (eds.), Actas del Sexto Congreso Internacional de Hispanistas, Toronto, University,

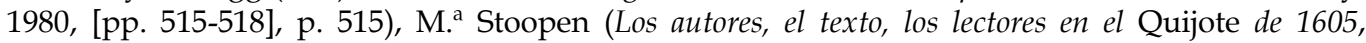
México, Universidad Nacional Autónoma, 2002, pp. 315-17) y quizá el propio Cervantes -"Este fin tuvo el ingenioso hidalgo de la Mancha, cuyo lugar no quiso poner Cide Hamete puntualmente [...]" (II, 74 [p. 1221]), si no es que resume entonces el 'segundo autor y editor' lo que se le tradujo que había escrito Benengeli al final de la 'segunda parte' de su Historia-; cf. J. A. Parr, op. cit. en n. 33, p. 402, n. 6, así como G. Haley (op. cit. en n. 32 [sobre todo, págs. 179 ss.]) y M. Moner (Cervantès conteur. Écrits et paroles, Madrid, Casa de Velázquez, 1989, p. 69 y n. 51). Para R. M. Flores (op. cit., p. 11), el anónimo sería tan solo el traductor de la parte inicial del manuscrito de Cide Hamete.
} 
manipulado..." que "no interviene activamente ni en la acción ni en la narración" (J. A. Parr, op. cit. en n. 33, II, p. 404) y que fue imaginado tardíamente por Cervantes (ya que no aparece hasta el capítulo 9 o incluso, más tarde, en I, 16) para resaltar las distintas 'Partes' en las que decidió dividir su obra; 35 su versión, con todo, "sí es presencia, sobre todo en el Quijote de 1615" (J. A. Parr, op. cit. en n. 8, p. 49). Y es que desaparece del Quijote I tras el capítulo 27, seguramente porque demoraba el desarrollo de los hechos y complicaba sobremanera los planos de la narración, además de porque desviaba la atención de los sucesos de la historia hacia un personaje muy secundario y marginal, que no resultaba uno de sus protagonistas. Por ello, Cervantes decidió pasar de múltiples fuentes de la historia a una sola; de varios autores previos, a uno solo (Cide Hamete); de uno a varios intermediarios; de un autor anónimo desconocido a un sabio historiador árabe con pruritos de narrador (cf. Haley, op. cit. en n. 32, pp. 183-84]) y, al fin, a una narración básicamente omnisciente de origen no explicitado $(v . i$.$) .$

-4. Versión castellana de la Historia de Cide Hamete realizada, a partir de un manuscrito original en árabe (con dibujos y anotaciones del autor), por el anónimo traductor aljamiado morisco (I, 9 ss. [p. 108 ss.]) de cuyas "credenciales [...] no sabemos nada" (J. A. Parr, op. cit. en n. 33, II, p. 407); es un mero "intermediario" cuya "intervención no constituye más que un aspecto muy accidental del recurso paródico a los pseudoautores, traductores e intérpretes de lenguas clásicas [...] tan frecuentes en las ficciones caballerescas, como el propio pseudohistoriador Benengeli", tal como señalara M. de Riquer (apud Paz Gago, op. cit., p. 44b]). Con todo, es evidente que no trabajó sobre las palabras del texto "sin quitarles ni añadirles nada, del mesmo modo que [en la obra] se refiere" (I, 9, [p. 109]; cf., por ejemplo, II, 18 [p. 772]).

-5. Versión del «segundo autor»y 'primer editor y comentador' del texto (I, 8 y 9 ss. [pp. 105 ss.]); es un "narrador dramatizado" y "un lector frustrado, curioso e ingenuo" (J. A. Parr, op. cit. en n. 33, II, p. 403) que muestra diversas tachas; ${ }^{36}$ para E. C. Riley, es "who presents the work to

\footnotetext{
${ }^{35}$ Cf. Riley, op. cit. en n. 1, p. 322, así como G. Stagg, "Sobre el plan primitivo del «Quijote»" (en F. Pierce y C. A. Jones [dirs.], Actas del Primer Congreso Internacional de Hispanistas, Oxford, The Dolphin Books, 1964, pp. 463-471), p. 469 y "Cervantes revisa su novela (Don Quijote, I Parte)" (Anales de la Universidad de Chile, 140 [1966], 5-33), pp. 11 ss. y E. M. Anderson y G. Pontón Gijón, "La composición del «Quijote»", en F. Rico (dir.), op. cit. en n. 2, I, pp. CLXXVII-CLXXVIII.

36 "Es importante notar que queda desacreditado por varios motivos el segundo autor también, entre ellos el que lo lea todo [...] con la misma delectación, sin discriminar; el que no capte la
} 
De versiones y autores ficticios en El Quijote: a vueltas con el ...

the public", así como "whom we may, for practical purposes, identify with Cervantes" 37 . En cualquier caso, se trata del "curioso" "que tuvo cuidado de hacerla traducir de arábigo en nuestro vulgar castellano" (II, 3, p. 647), aunque, a pesar de lo dicho en 1, 9 (p. 109), no edite la obra tal como la vertió el morisco y se permita parafrasear, citar, abreviar o comentar "el texto traducido de Cide Hamete" (F. Martínez-Bonati, op. cit., pp. 93-94). Evidentemente, es "otra máscara del autor" (Paz Gago, op. cit., p. 44b), que supuestamente utiliza un "relato ya consumado de esta historia", enjuiciándolo, incluso irónicamente, en ocasiones ${ }^{38}$. Y, si no me equivoco ( $v$. una opinión contraria, por ejemplo, en G. Haley [op. cit. en n. 22, p. 271] y Paz Gago [op. cit., p. 45c]), es él "el autor desta historia", "el fidedigno autor desta nueva y jamás vista historia" mencionado en I, 52 (p. 591), tras desaparecer de la obra Cide Hamete y su traductor aljamiado (I, 28 ss.) y quedarse en solitario como eje del punto de vista narrativo ficticio de la novela (una tercera persona a un tiempo omnisciente y propia de un personaje secundario), esto es, como narrador ficticio; de ahí, entre otros aspectos, la alusión a "la curiosidad y diligencia [con la que] ha buscado los hechos que don Quijote hizo en su tercera salida"; a cómo "no ha podido hallar noticia de ellos, a lo menos por escrituras auténticas" (I, 52, p. 591); a que los "pergaminos [estaban] escritos con letras góticas, pero en versos castellanos", y a que "aquí pone" "los que se pudieron leer y sacar en limpio" (ibid.).

-6. "voz editorial [cristiana]" final (J. A. Parr op. cit. en n. 8, p. 48 y 49]), "supernarrador" o "autor definitivo", también anónimo y poco fidedigno, cuya existencia se deduce "por extensión de la trayectoria implícita en la serie que va desde los personajes-autores a Cide Hamete, el traductor y el segundo autor" (El Saffar, op. cit., p. 298). ${ }^{39}$ (Este sería el

postura negativa del primer autor frente al personaje [...] el que contrate al primer bilingüe con quien tropieza en la calle para que le haga la traducción, sin investigar [...] sus credenciales o su experiencia; etc." (J. A. Parr, op. cit. en n. 8, p. 49).

37 Op. cit. en n. 29, p. 808. Así lo entienden también, por ejemplo, Cros (op. cit., pp. 232 y 233), R. B. Tate ("Who wrote Don Quixote?", Vida Hispánica, 25 [1977], 6-12, p. 6), Riley (op. cit. en n. 1, pp. 74 y 319), I. Lerner (Lecturas de Cervantes, Málaga, Universidad, 2005, p. 431)...

38 R. M. Ford “Narración y discurso en el Quijote", CH, 430 (1986), 5-16, pp. 8 y 12.

39 Cf. J. A Parr, op. cit. en n. 33, pp. 402 y 406-7, para quien "es poco probable que el segundo autor se refiriera a sí mismo en tercera persona” (p. 403). Según él, el 'supernarrador' "ejerce [desde I, 8] y en adelante un control silencioso sobre la organización del texto y sobre las demás voces que entran en juego" (ibid.); "es la voz narrativa de mayor autoridad, porque es la voz que redacta y manipula todo el discurso" (ibid., p. 405); acaba convirtiéndose en "supernarrador" porque "habla [del] segundo autor en tercera persona", informa del hallazgo de la versión de Cide Hamete (I, 89) y manipula "todo el discurso" (interrumpiendo, incluso, "la traducción [del morisco] con sus 
plano fundamental del 'narrador principal' de que habla Paz Gago [op. cit., p. 44c]). Es un agente autorial que sirve para organizar y dar coherencia a las diferentes partes y planos del relato "y que acaba siendo un 'autor-editor'" (ibid., p. 44c).

-7. El "autor dramatizado del prólogo de 1605", «padrastro» de la novela;40 de acuerdo con Ch. Pressberg (1995), M. ${ }^{\text {a }}$ Stoopen (op. cit., p. 271) destaca cómo existe un narrador que "debió de haber compuesto la versión final de la historia verdadera y los preliminares [...] a la vez que es el único autor que tiene acceso a todas las fuentes" -en el que parecen condensarse, en parte, las funciones de los autores 6-7 aquí señalados-.

-8. El "oculto autor implícito" (R. S. El Saffar, op. cit., p. 298]) -"ente teórico [que] es la voz del autor real dentro del texto y [...] la suma de las creencias, valores y perspectivas articulados en [él]" y que se deja sentir, sobre todo, en "los elementos extraficcionales como, por ejemplo, el título, los prólogos (donde aparece como autor dramatizado), las dedicatorias, los versos preliminares y la tabla de los capítulos" (J. A. Parr, op. cit. en n. 33, p. 402])-, “autor inferido o autor-en-el-texto" (J. A. Parr, op. cit. en n. 8, p. 50]). ${ }^{41}$

comentarios editoriales a cada rato, sobre todo en el Quijote de 1615" -aunque muy bien pudieran deberse estos al «segundo autor» $\mathrm{y}$ 'primer editor y comentador' del texto-): “[...] es el encargado de la narración y su control de la misma se hace evidente" (J. A. Parr, op. cit. en n. 8, p. 49; cf. J. A. Parr, op. cit. en n. 33, pp. 402-4]). Su "función es enlazar el final de la Primera parte del [texto de 1605 (caps. I, 8-9)] con el segundo autor, que inmediatamente se hace responsable [en primera persona] de la búsqueda y transmisión del resto" (R. S. El Saffar, op. cit., pp. 297-98; véase Quijote I, 8, [p. 104]). Según G. Haley (op. cit., p. 271), "reaparece en el capítulo final de la Primera parte para hacer las últimas observaciones. Es el intermediario más distanciado de don Quijote y, al mismo tiempo, el más íntimo, tanto para el libro como para el lector [...] es quien establece la relación entre el autor implícito y el lector ideal [...]" en I, 52 (p. 591) (véase supra, 'autor' -5). Para estas divergencias, nada extrañas - por lo demás- a causa de lo problemático del asunto (véase infra,

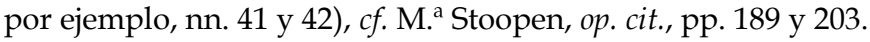

40 J. A. Parr, op. cit. en n. 8, pp. 50-51. "[...] el término «padrastro» sirve muy bien para sugerir el distanciamiento logrado por la mediación de la escritura" (p. 50) y los distintos planos narrativos usados en la obra; así, "La responsabilidad está repartida, la autoridad queda pendiente, y el lector tiene que hacer cara al dilema de una contextualización sin límites" (p. 51); cf. M. 'Stoopen, op. cit., pp. 277-78. De ahí también, seguramente, el "Compuesto por Miguel de Cervantes Saavedra" de la portada del libro en 1605 (de que se ocupó ya M. Molho, op. cit., pp. 275-76).

41 Para H. Mancing (op. cit., pp. 192-93) es éste un autor que equivale a Cervantes. Véase, además, S. Fernández Mosquera (op. cit., pp. 64-65), para quien hasta "cinco voces [...] se pueden distinguir en la novela aunque dudemos en ocasiones quién de ellos interviene": "Autor de los 8 primeros capítulos, el Editor, el Traductor, Cide Hamete Benengeli y el Autor definitivo"; “Todos ellos son rastreables en el texto y ninguno de ellos ha de identificarse con Cervantes" (p. 65). 
De versiones y autores ficticios en El Quijote: a vueltas con el ...

\section{-9. El lector (real)}

No se agota, sin embargo, en ellos la compleja variedad de los puntos de vista, los planos, versiones y aproximaciones posibles a los sucesos relacionados con la historia de don Quijote y Sancho que Cervantes apunta o menciona sobre todo al final de la Primera parte de su obra magna -como ya advirtiera, por ejemplo, E. C. Riley-, ${ }^{42}$ y que pueden llegar a resultar, sin que se intente realizar aquí un análisis exhaustivo, hasta un total de siete (al menos):

\section{[-Hechos de don Quijote (y Sancho)]}

-1 . Versión de los personajes, sobre todo la mental de don Quijote (con "la narración que el Caballero cree que se está escribiendo sobre él y sus aventuras [...] es selectiva, halagüeña y muy pintoresca" y "establece un contraste magníficamente cómico e irónico con la historia que Benengeli narra en realidad"), 43 pero también la de los "narradores intradiegéticos", esto es, "los personajes a los que el narrador primario cede efectivamente la función narrativa” (J. M. ${ }^{a}$ Paz Gago, op. cit., p. 46c; vid. pp. 46c-48b])

-2. Los Anales de La Mancha (I, 2 [p. 48] y I, 52 [p. 591])

-3. Los documentos de los "archivos manchegos" mencionados en I, 52 (p. 591; véase, también, I, Prólogo [p. 12])

-4. Las "escrituras [no] auténticas" de los hechos de don Quijote citadas en I, 52 (p. 591)

\footnotetext{
42 Op. cit. en n. 1, pp. 337-338: “[...] de hecho hay en potencia un infinito número de versiones, interpretaciones y puntos de vista [en el Quijote]. Están englobadas en el Quijote mediante alusiones o deducciones, todas las posibles versiones parciales de la historia de Don Quijote. No tendría sentido especular acerca de cuál de estas versiones es la más acertada o la más completa, puesto que el objeto de todas ellas es producto de una invención. Pero Cervantes ha conseguido que su invención parezca independiente de todas las versiones, utilizando el sencillo artificio de llamar la atención discretamente sobre la variedad de las posibles interpretaciones".

${ }^{43}$ E. C. Riley, op. cit. en n. 29, pp. 807 y 814 ss. y op. cit. en n. 30, p. 201. "Esta versión personal de Don Quijote no debe ser rechazada a la ligera porque sea una fantasía frustrada. Es significativa en dos sentidos y tiene una potencia singular": por contraponer al romance de caballerías la ficción 'realista' y porque, aun siendo del todo mental, provoca las acciones del personaje central (ibid., pp. 201-202; cf. M. I. Gerhardt, Don Quijote, la vie et les livres, Amsterdam, 1955, pp. 34-35, y E. C. Riley, op. cit. en n. 1, pp. 312-313).
} 
-5. Las memorias orales de los hechos de don Quijote -o del personaje- conservadas en La Mancha (ibid.; véase I, 9 [p. 106] y I, Prólogo [p. 18])

-6. Los "pergaminos escritos con letras góticas, pero en versos castellanos, que contenían muchas de [las] hazañas" de don Quijote, entre otras cosas (ibid.; véase pp. 592-96), quizá a partir del Amadís y Las Sergas de Esplandián (cf. E. C. Riley, op. cit. en n. 30, pp. 52-53]); de ellos se editan tan solo, al final de la novela, "Las palabras primeras" y unos cuantos versos (véase I, 52 [pp. 592-96]) "de los Académicos de la Argamasilla" "que se pudieron leer" (ibid., p. 597).

-7. Los papeles góticos de "carcomida letra", encontrados junto a los anteriores y entregados "a un académico para que por conjeturas los declarase [...] Tiénese noticia que lo ha hecho [...] y que tiene intención de sacallos a luz, con esperanza de la tercera salida de don Quijote" (I, 52 [p. 597]). (Este parece ser el posible punto de partida de una continuación cervantina de la novela, que, sin embargo, no podía incluir la tercera salida de don Quijote, lógicamente [pues en esta, entre otras cosas, se habla del libro editado en 1605 en el que no se había podido incluir el contenido de aquellos]).

Por el contrario, en el Quijote de 1615 ("una novela diferente" a la de 1605 , no se olvide [v.s.], y más cohesionada y centrada en don Quijote y Sancho) se presenta una reducción y reelaboración del juego de autores y planos ficticios anteriores (aunque no haya un acuerdo definitivo respecto de su número y sus funciones, así como a las intervenciones que pertenecen a cada uno), ${ }^{44}$ que quedan reducidos básicamente a tres 'autores' (casi a pesar de Quijote, II, 3 [p. 649]: "[...] que se holgaran se les hubiera olvidado a los autores della [...]" [mencionados ya antes] y del recuerdo de la Primera Parte), con sus versiones:

[- Hechos de don Quijote y Sancho].

-1a. Cide Hamete Benengeli, convertido ahora en "su autor primero" (II, 40, p. 949; véase también II, 2, 24 y 70). Es presentado esta vez como más escrupuloso y relacionado con el 'primer autor' anónimo del Quijote de 1605 por "omniscient and ubiquitous" (Tate, op. cit., p. 8]), aunque juzga sucesos y su veracidad, realiza comentarios técnicos o estéticos,

${ }^{44}$ Cf. S. Fernández Mosquera, op. cit., pp. 47-53 y 65 y J. M.Paz Gago, op. cit., p. 46b, así como J. Á. Ascunce, op. cit., pp. 51 ss. 
De versiones y autores ficticios en El Quijote: a vueltas con el ...

omite situaciones de la historia (ibid., p. 9, nn. 8, 11 y 10) y resulta más cercano a un novelista que a un historiador (cf. Gerhardt, op. cit., p. 11]). Tiene además, en el Quijote II, una predominante "función testimonal" -que confiere verosimilitud e independencia a la historia y los personajes-, hasta el punto de que nada parece escapar ahora a su férreo control45; con todo, resulta claro que no siempre presencia lo que cuenta (ibid., p. 17) y que el lector no puede fiarse de él, pues oculta información, confunde... Asimismo, se muestra capaz de "salirse del campo de la pura ficción para pronunciarse sobre hechos acaecidos en la realidad extratextual" (Martín Morán, op. cit. en n. 17, p. 181).

Es mencionado, al menos, en 39 ocasiones y utilizado ahora, comúnmente, para iniciar capítulos (II, 1, 8, 24, 27, 40, 44, 50, 52, 53, 60 y 73) o para cerrarlos (II, 47, 61 y 74) con un abrupto corte temporal, lógico o del hilo narrativo o argumental de la historia 46 - clara herencia de su función en 1605 al comienzo o al final de las partes II-IV de la obra, más tarde desechada-; y, sobre todo, se convierte en el cronista oficial y el autorizado historiador de los hechos de don Quijote que "would give internal coherence to the tone of the narrative, and would set his work [...] in the romances-of-chivalry tradition" (Flores, op. cit., p. 5), que, además, les permitía distanciarse de la historia que contaban al narrador y al verdadero autor de la novela (cf. ibid.).

- b. Versión árabe original de la Historia de don Quijote de la Mancha escrita por el anterior (que no se reproduce verbatim habitualmente [véase, sin embargo, II, 27 (p. 855)], sino que es parafraseada, glosada, juzgada, abreviada, analizada... por el morisco aljamiado $\mathrm{y}$, sobre todo, por el segundo autor y editor del texto [cf. R. M. Flores, op. cit., p. 11]).

-2a. Traductor aljamiado morisco (véase supra).

— b. Versión castellana de este de la Historia de Cide Hamete.

-3a. «Segundo autor» - aunque nunca se le cite así en el Quijote II (cf. Martín Morán, op. cit. en n. 17, p. 160])- y 'primer editor y comentador' del texto (aquí ya sí identificable, lejana o indirectamente, con Cervantes; cf. Flores, op. cit., pp. 6 y 11 y Socrate, op. cit., pp. 38 ss.). Nótese, en cualquier caso, cómo "no dice nada acerca del modo en que superó la

45 Cf. J. M. Martín Morán, "La función del narrador múltiple en el Quijote de 1615", AC, XXX [1992], 9-65, pp. 16 y 19.

${ }^{46}$ Cf. R. S. Willis, Jr., The Phantom Chapters of the Quijote, New York, 1953, pp. 84 ss. 
penuria de noticias sobre los hechos del caballero"; cómo "vuelve a echar mano del cronista árabe como si nada hubiera ocurrido" en el Quijote I (Martín Morán, op. cit. en n. 45, p. 15]) y cómo esta máscara le sirve a Cervantes para utilizar un supuesto editor más crédulo y menos lógico, suspicaz y realista de lo que tendría que haber sido él mismo si hubiera tenido que juzgar una narración como la de Cide Hamete (y una historia como la del loco don Quijote en mitad de la España del momento).

— b. Versión definitiva de este, 'primer editor y comentador' del texto.

[-4. "voz editorial final", "supernarrador" o "autor definitivo", si quien se deja sentir en II, 74 no es el "segundo autor" anterior (v. s. n. 34)-].

-5. El autor "manifiesto" del prólogo (de nuevo con muchos elementos de contacto con el 'autor real') (cf. M. 'Stoopen, op. cit., pp. 301 ss.).

-6. El 'oculto autor implícito' 47

-7. El lector (real)

Por lo que se refiere a los otros planos y versiones ficticios de la novela de 1615, debe notarse una mayor reducción respecto de 1605 -que muestra la revisión a la que sometió Cervantes los materiales y técnicas que utilizaba-:

-1. Versión de los personajes (sobre todo, don Qujote y Sancho) (v. s.).

-2. Como ocurriera en la Primera Parte con los Anales de La Mancha (I, 2 [p. 48]) y otros documentos u obras, en la Segunda es el propio Quijote de 1605 el que funciona como texto que transmite una parte de las 'verdaderas' aventuras de don Quijote y Sancho (II, 2-4).48

\footnotetext{
${ }^{47}$ Cf. M. Stoopen, op. cit., p. 305-10, así como J. A. Parr, "Narración y transgresión en el Quijote", en Confrontaciones calladas: El crítico frente al clásico, Madrid, Orígenes, 1990, [pp. 107-26], pp. 117 ss. y J. M. Martín Morán, "La débil autoridad del padrastro del Quijote", en III CINDAC (octubre de 1997), ed. A. Bernat Vistarim, Palma, Universitat de les Illes Balears, 1998, [pp. 277-95], pp. 281-82. 48 Cf. E. C. Riley, op. cit., p. 312: “[...] en la segunda parte de la obra, [se] sitúa a don Quijote y a Sancho frente a la evidencia de su celebridad literaria. Así, el hecho histórico de la fama de la primera parte de la novela queda introducido en la ficción de la siguiente, y al hacer esto Cervantes elimina la frontera que separa el mundo interior de la obra artística del mundo viviente
} 
De versiones y autores ficticios en El Quijote: a vueltas con el ...

-3. Las "escrituras [no] auténticas" de I, 52 (p. 591), y los falsos autores de I, 1-2, serán relevados en el Quijote II, en exclusiva (y quizá durante todo él), por la novela apócrifa de 1614 y por Avellaneda ${ }^{49}$ (v. i.).

-4. Las memorias orales guardadas en La Mancha no ya de los hechos de don Quijote -como en 1605-, sino de la existencia de una narración de los mismos (cf. J. M. Martín Morán, op. cit. en n. 17, pp. 156-57).

Diversas son las cuestiones de relativa importancia que todo lo anterior suscita; pero, ciñéndome ahora a la aclaración del inicio de II, 44, me gustaría destacar cómo algunos de los desajustes del punto de vista que muestra el Quijote $^{50}$ provienen, en gran medida, tanto del deseo de Cervantes de hacer más rica y compleja la novela que escribía como de la peculiar composición de esta. ${ }^{51}$ En relación con ello, entonces, debe tenerse en cuenta que bajo el texto de la obra tal como hoy lo conocemos hay varias etapas compositivas $y$ (re)organizativas; y que, en ellas, se fueron sucediendo cambios de orientación de la narración o revisiones y desplazamientos, modificaciones, supresiones... de la materia narrativa que, en lo que se refiere al punto de vista ficticio de la obra, la llevaron desde 1) el trabajo casi historiográfico de un primitivo narrador omnisciente en un "cuento" o novelita ejemplar quizá inicialmente breve (caps. I,1-...18 actuales) a 2) la labor histórica de Cide Hamete Benengeli, traducida por el moro aljamiado y editada en primera instancia por el segundo narrador de la obra (caps. I, 9-27) -para lo que se simuló, en I, 1-8, la existencia de un texto previo de un primer narrador, anónimo, sobre la base del esfuerzo de otros historiadores y autores anteriores, versiones, documentos...- $y$, finalmente, a 3) la exposición ('histórica') de un "autor" omnisciente indeterminado, desaparecido del primer plano narrativo y al que solo se da carta de naturaleza

exterior" (véase, además, ibid., p. 333). Con todo, don Quijote, "con esa prudencia que muestra algunas veces cuando sus ilusiones pueden correr el riesgo de ser destruidas por la realidad, nunca trata de leer el libro que se ha escrito sobre él (hacerlo habría producido, ciertamente, enormes complicaciones)" (ibid., 313).

49 Cf. E. C. Riley, op. cit. en n. 1, p. 333: "La verdadera primera parte y la falsa segunda parte adquieren la misma importancia que habían tenido, en los capítulos anteriores, la historia verdadera y las narraciones caballerescas falsas, respectivamente", así como M. I. Gerhardt, op. cit., pp. 37 ss.

50 A causa de ellos, E. C. Riley (op. cit. en n. 30, p. 200) aconsejaba: "No habría que hacer caso omiso de todas las [anteriores] distinciones ni andar con tiento a través de ellas; habría simplemente que distinguir razonablemente los principales planos de intervención del autor".

51 Cf. G. Stagg (véase supra n. 35), R. M. Flores ("Cervantes at work: the writing of Don Quixote, Part I", JHPh, III, 2 [1979], pp. 135-60), E. M. Anderson-G. Pontón Gijón (op. cit., I, pp. CLXX-CLXXX) y F. Rico (op. cit. en n. 10, caps. II-IV [especialmente, pp. 111-23 y 229-37]). 
en I, 52 [p. 591], aparentemente -toda vez que Cide Hamete había llegado a ser un "estorbo" y había desaparecido de la novela después de I, 27 (hasta el punto de no ser siquiera mencionado de pasada, al final del Quijote de 1605, en los poemas preliminares de la obra o en su "Prólogo" [cf., por ejemplo, R. M. Flores, op. cit. en n. 50, p. 149])-: de este modo, es claro que se desentendía Cervantes, en la práctica, de la estructura 2) antes señalada.

Sin embargo, cuando el alcalaíno se plantee la continuación de las aventuras de don Quijote en 1615 (seguramente como contrapunto de la labor apócrifa y las peculiares 'innovaciones' de Avellaneda sobre el texto y la historia de 1605), 52 usará como eje de su punto de vista el constructo 2) de supra en 1605 desechado de manera implícita y sin más explicaciones después del final de I, 27 (con Cide Hamete, el traductor aljamiado y el segundo autor y editor de la historia que tanto le habían dificultado a Cervantes la narración de los hechos de don Quijote y Sancho con las continuas alusiones al historiador moro y su obra al comienzo de cada una de las partes de la novela, por tener que dar cuenta allí de su persona[lidad] y de su relación con los hechos que se presentaban). Con todo, será utilizado en 1615 con una variante respecto de 1605: la continua utilización de esa fórmula de 2), propia de la Primera parte del Quijote, en los diversos capítulos de la novela hasta la mención expresa de su homónimo apócrifo de Avellaneda en II, 59 (de hecho, Cide Hamete parece desaparecer, de nuevo, entre II, 60 y II, 74) para, en último término, hacer problemática y complicar la narración, obligando a sus lectores a ser críticos y a analizarla (tras poner en cuestión la realidad literaria allí representada por medio de los planos, perspectivas y puntos de vista distintos que afectan a la historia narrada y a la propia narración de la misma). Conseguía así el autor conectar con su propia obra y labor de 1605 (dándole una continuidad y, también, una conexión y una prosapia de las que carecía la obra apócrifa de Avellaneda), al tiempo que conformaba una complejidad narrativa y una variedad de planos y perspectivas que le permitían a Cervantes seguir profundizando en el análisis y la transposición de lo real -sobre todo- y lo literario y hacer más compleja la narración y su punto de vista de una forma que acababa respondiendo "al complicado entramado autorial de Avellaneda" (Martín Jiménez, op. cit. en n. 22, pp. 344-45) con su mejoramiento y superación.

5. Así las cosas, ha llegado el momento de abordar el sentido último del inicio de II, 44. Y, para ello, debe tenerse en cuenta que el pasaje que me ocupa tiene dos partes por completo diferenciadas.

5.1. En relación con la primera de ellas («Dizen que en el propio original desta historia se lee que, llegando Cide Hamete a escriuir este capítulo, no le

${ }^{52}$ Cf. A. Martín Jiménez, op. cit. en nn. 21 y 22. 
De versiones y autores ficticios en El Quijote: a vueltas con el ...

traduxo su intérprete como él le auía escrito»), debe notarse cómo «Dizen» está puesto en boca del narrador ${ }^{53}$ y puede referirse tanto al 'traductor' morisco aljamiado ${ }^{54}$ como, más probablemente, a esa memoria popular o tradición oral que, en el Quijote de 1615 -y frente al recuerdo oral de las hazañas de don Quijote en la primera parte de la obra (véase supra)—, "conserva el recuerdo del manuscrito de Cide Hamete" (tal como destaca J. M. Martín Morán, op. cit. en n. 17, pp. 156-57) ${ }^{55}$ como a ambos. Recuérdese, en relación con ello, cómo en II, 12 (p. 721), por ejemplo, también se señala "que hay fama, por tradición de padres a hijos, que el autor desta verdadera historia hizo particulares capítulos della" (véase, además, II, 3 [p. 649]).

Por su parte, el "propio original desta historia" debe entenderse no como una versión anterior a la de Cide Hamete (tal como quería F. Locke, op. cit., p. 54, por ejemplo), sino como el manuscrito original árabe de la historia escrita por Cide Hamete Benengeli, con anotaciones marginales también manuscritas e incluso dibujos en el caso de la primera Parte (cf. I, 9 [pp. 108 y 109], por ejemplo), que el morisco aljamiado supuestamente utilizaba -aunque sin saberse muy bien de dónde había salido en la continuación de 1615- como base para verter la historia de las aventuras de don Quijote y Sancho al español. ${ }^{56}$ Es lo que se deduce también de Quijote, II, 24 (p. 829):

Dice el que tradujo esta grande historia del original de la [historia] que escribió su primer autor Cide Hamete Benengeli que, llegando al capítulo de la aventura de la cueva de Montesinos, en el margen dél estaban escritas de mano del mesmo Hamete estas mismas razones [...] (cf., para lo intercalado aquí, F. Rico [dir.], ed. cit. en n. 2, I, p. 829, n. 1).

Por lo que respecta a la construcción absoluta de gerundio ('llegando Cide Hamete a escribir este capítulo'), debe advertirse tanto que, de acuerdo con H. Keniston 57 , llegar a [+ inf.] puede actuar aquí como auxiliar (y expresando "achievement") - por lo que debe entenderse en lo citado: 'habiendo Cide

53 Cf. J. I. Ferreras (ed.) (Segunda Parte del Ingenioso caballero don Quijote de La Mancha, Madrid, Akal, 1991, p. 293, n. 1) y Quijote, II, 12 (p. 721): “Digo que dicen que dejó el autor escrito [...]".

54 A pesar de opiniones como la de A. del Campo (apud V. Gaos, op. cit., II, p. 588, n. 4) y E. C. Riley (op. cit. en n. 30, p. 121), o extrañezas como la de Á. Basanta (op. cit. de 2005, p. 1279, n. 1).

55 Véase supra nota 11. J. A. Parr (op. cit. en n. 8, p. 52), por su parte, entiende el pasaje como una muestra de "oralidad encajada en la escritura"; cf. S. Hutchinson, op. cit., pp. 127-129.

${ }_{56}$ Cf., por ejemplo, D. Clemencín (v. s.) y J. J. Allen (ed. cit., II, p. 349, n. 1). Por su parte, la idea de F. W. Locke (op. cit., p. 54) de que existía un 'original' anterior ("that lies behind") a la versión árabe de la Historia de Cide Hamete Benengeli, conocido sólo oralmente por el 'segundo autor' de la novela, es aceptada por autores posteriores como H. Percas de Ponseti (op. cit., I, pp. 95-96), H. Mancing (op. cit., p. 194) y J. A. Parr (op. cit. en n. 13, p. 60).

57 The Syntax of Castilian Prose. The Sixteenth Century, Chicago, Ill., University, 1937, p. 464, § 34.55. 
Hamete escrito este capítulo' (cf. J. E. Hartzenbusch, op. cit. de 1874, p. 153b, n. 1360 [v. s.]) - como que puede resultar llegar, quizá más acertadamente, un verbo predicativo con valor de movimiento 58 - lo que, al menos en apariencia, facilitaría la inclusión de comentarios del autor sobre la labor del intérprete o traductor que trabajaba con él-.

En lo que se refiere, en exclusiva, al "intérprete" mencionado en el pasaje, debe notarse que no es posible que se trate del traductor aljamiado morisco de I, 9 ss. -quien, no se olvide, estaba traduciendo la Historia de don Quijote de La Mancha que encontrara en Toledo el segundo autor y primer editor del texto del Quijote algún tiempo o, mejor, bastante después de que de Cide Hamete Benengeli la compusiera-, entre otras cosas, porque no es demasiado factible que apareciera mencionado en el original árabe de éste que se versionaba en castellano. (El siguiente esquema lo muestra claramente, ya que hay que pensar que cada 'autor ficticio' pudo conocer y hacer uso del trabajo del anterior o de los anteriores, pero nunca del de los posteriores a él y su labor:

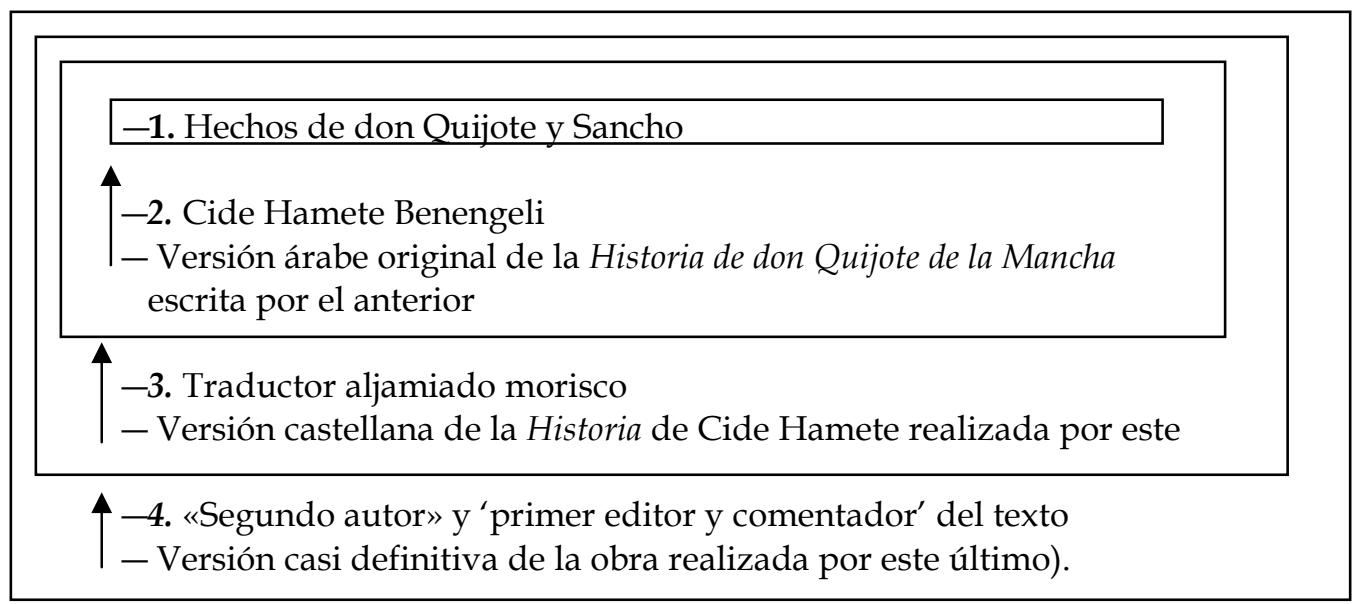

A no ser que, en este caso particular, se quiera echar mano del hecho de que Cide Hamete Benengeli parece ser, además de "historiador" árabe (II, 3 [p. 649]) o "filósofo mahomético" (II, 53 [p. 1061]), un "sabio encantador" (I, 2 [p. 47] y II, 2 [p. 645]), un 'mago' -lo que puede tranquilizar a don Quijote y a Sancho, entre otros, o explicar inicialmente las informaciones minuciosas que se presentan en

\footnotetext{
58 Véase Quijote, II, 5 (p. 663) (“Llegando a escribir el traductor desta historia este quinto capítulo, dice que le tiene por apócrifo, porque [...]”) y II, 10 (p. 700) ("Llegando el autor desta grande historia a contar lo que en este capítulo cuenta, dice que quisiera pasarle en silencio, temeroso de que no había de ser creído, porque [...]"). En ambos casos se trata de una nueva fórmula de inicio de capítulo, prácticamente idéntica.
} 
De versiones y autores ficticios en El Quijote: a vueltas con el ...

la obra, pero está por completo alejado de la visión y la forma de componer Cervantes su universo narrativo y el juego de 'autores', planos, puntos de vista... ficticios de su obra59-. Sin embargo, el propio texto del Quijote casi impide tal equiparación, pues, en la Segunda parte, el morisco aljamiado que vierte al castellano la crónica de Cide Hamete es siempre mencionado como "[e]l traductor desta historia" (II, 5 [p. p. 663] y II, 18 [p. 772]) o "su traductor" (II, 27 [p. 855]), mientras que, cuando se utiliza el término "intérprete" en relación con la historia de don Quijote y Sancho en la Primera parte (I, 9 [p. 108]) en exclusiva, su uso tiene un carácter claramente abstracto y genérico, no individualizador:

Y puesto que los conocía no los sabía leer [los caracteres arábigos del cartapacio que hojeaba], anduve mirando si parecía por allí algún morisco aljamiado que los leyese, y no fue muy dificultoso hallar intérprete semejante, pues aunque le buscara de otra mejor y más antigua lengua le hallara (I, 9 [pp. 107-8]).

Debido a lo anterior, a mi juicio, ese "no le tradujo su intérprete como él le había escrito" del comienzo de II, 44, no hay más remedio que entenderlo con el sentido, literal, de que Cide Hamete Benengeli -autor "arábigo y manchego" (I, 22, [p. 235]), esto es, un autor morisco moderno, casi coetáneo a los sucesos, de La Mancha- supuestamente utilizaba un 'traductor' (no se olvide que en castellano, hasta el Diccionario de Autoridades cuando menos, resultaban términos sinónimos intérprete y traductor) al árabe clásico o coránico, seguramente, desde un dialecto árabe peninsular, la aljamía propia de los moriscos hispanos de los siglos XVI y XVII -más probablemente- o el propio español. En relación con ello, hay que tener en cuenta, en principio, la dicotomía o "diglosia característica" del árabe -también en Al-Ándalus-, "básicamente inalterada hasta nuestros días"; a causa de ella, se puede documentar 1) un "registro formal más prestigioso [y conservador], imbatiblemente apoyado por la recitación coránica y las manifestaciones cultas", que acabaron codificando los gramáticos (esto es, el árabe preclásico); y 2) el uso de dialectos de tipo neoárabe (o árabe medio) que se terminó imponiendo "en el registro coloquial de Alandalús, como en el resto del mundo arabófono, pronto y decididamente, sin

${ }^{59}$ Cf., en este sentido, la opinión de E. C. Riley (op. cit. en n. 29, pp. 808-10; op. cit. en n. 1, pp. 323, 324-327, 334 y 338; y op. cit. en n. 30, p. 200), G. Haley (op. cit. en n. 22, p. 270) o C. Segre (Las estructuras y el tiempo, Barcelona, Planeta, 1976, p. 189). Véase Quijote, I, 3 (p. 56), así como una visión contraria en H. Percas de Ponseti (op. cit., I, p. 168), C. I. Neupalsing (op. cit., p. 516) o F. de Toro (op. cit., p. 643). El propio E. C. Riley (op. cit. en n. 1, p. 321), sin embargo, explicaba cómo "Sólo en muy raras ocasiones cree don Quijote que Benengeli influye en ellos sobrenaturalmente" (véase Quijote I, 19 o I, 21), pero nunca el segundo autor (o el supernarrador). 
dejar casi residuos del otro". 60 A esto puede añadirse, incluso (de acuerdo con Á. Galmés de Fuentes), ${ }^{61}$ la suposición de que, en al-Andalus, pudiera desempeñar el castellano el segundo de los papeles aquí señalados.

Habría pues en la situación lingüística meridional de la Península, en principio, una "lengua oficial de registro alto" - usada para la escritura, finalmente- y "unos dialectos" o un "haz dialectal andalusí", en los que "el uso cotidiano hallaba su cauce" (F. Corriente, op. cit.., p. 33) y que con el paso del tiempo cederían "totalmente el puesto al romance [recuérdese la literatura aljamiada, por ejemplo], situación que no parece haber tenido más excepción importante que la del Reino de Valencia, según Barceló" (ibid., p. 34), o la del Reino de Valencia y Andalucía, según Á. Galmés de Fuentes (op. cit., p. 21). Según este último autor, por tanto, solo los moriscos de estas zonas "eran arabófonos" (ibid., p. 29) - es decir, tenían como lengua materna y coloquial el árabe, "que mantuvieron [...] hasta el día de la expulsión" (ibid., p. 21)—, a diferencia de lo que ocurría en Castilla y Aragón, cuyos moriscos eran "hispanófonos, que habían abandonado el árabe, siendo para ellos el español la lengua materna y coloquial" (ibid.). ${ }^{62}$

De esta forma, se llega a una comprensión casi literal de la primera parte del pasaje que me ocupa, en un sentido en buena parte apuntado claramente por J. G. Weiger, quien, sin embargo, se extrañaba -lógicamente- de que

[...] in II, 44 we are forced to envisage the translator as waiting for Cide Hamete to finish writing [...] But there is more. The sentence in II, 44 conveys that the translator's failure to translate faithfully what Cide Hamete was writing is a revelation that one reads in the original manuscript! (op. cit., p. 18).

5.2. Por ello hay que ocuparse también de la segunda parte del pasaje inicial de II, 44 de que aquí estoy tratando ("que fue vn modo de quexa que tuuo el Moro de sí mismo por auer tomado entre manos vna historia tan seca y tan limitada como esta de don Quixote..."). En relación con ella, debe notarse cómo su inicial "que fue un modo ["manera o forma" (Covarrubias)] de queja que

${ }^{60}$ F. Corriente, Árabe andalusí y lenguas romances, Madrid, MAPFRE, 1992, pp. 26 y 28-29.

61 "La lengua española de la literatura aljamiado-morisca como expresión de una minoría religiosa", REL, 16, 1 (1986), 21-38, p. 27.

62 Es bastante probable que Cervantes conociera de primera mano esta realidad lingüística del mundo árabe (tanto en el extranjero como en la Península ibérica -donde acabaría perseguido su uso-), dado su conocimiento del mundo musulmán durante su cautiverio -incluido el uso de la lingua franca ( $c f$. R. Schevill y A. Bonilla y San Martín [eds.], Comedias y entremeses, de M. de Cervantes, V, Madrid 1920, p. 248, n. a 61-1, y J. Canavaggio, Cervantes, Madrid, Austral, 2005, p. 130)- y de la vida española - en especial, la manchega y andaluza- por su continuo vagar por sus regiones y provincias de septiembre de 1584 a principios de 1612 (cf. ibid., pp. 192 ss. y 331). 
De versiones y autores ficticios en El Quijote: a vueltas con el ...

tuvo el moro de sí mismo" parece no tener sentido ni conexión alguna con lo anterior - tal como destacara D. Clemencín (véase supra)-. Sin embargo, debe advertirse cómo el antecedente del relativo neutro que (= 'lo cual') con el que se inicia esta segunda parte del pasaje puede ser tanto 'lo escrito por Cide Hamete al comienzo del capítulo en el original de la historia y que su traductor no había transcrito tal cual' como -mejor- 'que Cide Hamete escribiera al comienzo del capítulo correspondiente del original de su historia que su traductor no había transcrito verbatim lo por él compuesto'. No parece adelantarse demasiado al notar esto, salvo si se advierte que lo anterior $-\mathrm{y}$ lo supuestamente escrito por Cide Hamete en el original de su Historia- no fue más que el producto del malestar del árabe ("un modo de queja [...] de sí mismo") por la pesadez que sentía al tener que hablar siempre del hidalgo manchego y su escudero: "por auer tomado entre manos vna historia tan seca y tan limitada como esta de don Quixote, por parecerle que siempre auía de hablar dél y de Sancho, sin osar estenderse a otras digresiones y episodios más graues y más entretenidos". ${ }^{63}$ Esto es, ni más ni menos que, como forma de variatio (y para sobrellevar la pesadez de tenerse que ocupar siempre, y en exclusiva, de los dos protagonistas de la historia y de las aventuras relacionadas con ellos), Cide Hamete supuestamente colocó en el lugar correspondiente del comienzo del capítulo II, 44 de su Historia una digresión, por completo inventada por él y sin realidad ni razón alguna -como, por otra parte, también había hecho el autor real, Cervantes-, en la que se quejaba de que el hipotético traductor que estaba utilizando para verter lo que escribía (inicialmente ¿en árabe vulgar, en castellano, en aljamiado?) al árabe clásico o coránico no le había traducido entonces tal cual. Contravenía, así, Cide Hamete Benegeli, el teórico 'primer autor' o 'autor original' de la historia narrada en la Segunda Parte del Quijote, esa visión que del historiador se presentaba en la propia novela, acercándose peligrosamente a la definición que del poeta (en este caso, el novelista) se presentaba entonces: ${ }^{64}$

${ }^{33}$ Como es bien sabido, resulta esta queja por lo seco y limitado un tópico bien conocido en la época (cf. J. Bowle [ed.], Historia del famoso caballero don Quijote de la Mancha, III, Salisbury, Imprenta de Eduardo Easton, 1781, p. 110, n.] -que señaló cómo se tiene en cuenta aquí el prólogo a la Segunda parte de La Araucana, de Ercilla-, así como F. Sevilla Arroyo y A. Rey Hazas [op. cit., p. 886, n. 2] -quienes se hacen eco de la aparición del recurso en el Viaje de Turquía-).

${ }^{64}$ Cf. H. Percas de Ponseti (op. cit., I, 98-99: “[...] lo más grave es que [Cide Hamete] admite haberse aburrido con su papel de historiador y haber tomado el de artista, insertando «algunas novelas [...] de gran gala y artificio». El cronista se ha convertido en creador"), así como R. M. Ford (op. cit., pp. 12 y 14, y n. 18), E. C. Riley (op. cit. en n. 1, pp. 203-4 y 270) y R. S. El Saffar (op. cit., p. 290). 
-Así es -replicó Sansón-, pero uno es escribir como poeta, y otro como historiador: el poeta puede contar o cantar las cosas, no como fueron, sino como debían ser; y el historiador las ha de escribir, no como debían ser, sino como fueron, sin añadir ni quitar a la verdad cosa alguna (II, 3 [pp. 649-50]).

6. De todo lo anterior se deduce, por tanto, que todo el pasaje resulta una gratuita simulación o invención atribuida por Cervantes a Cide Hamete Benengeli - supuestamente molesto o aburrido a causa del asunto de la obra que 'escribía'-; y que 'lo que hay que entender en el pasaje inicial de II, 44 -en su primera parte, casi literalmente- es que el editor ficticio del Quijote - su innominado 'segundo autor' - informa de que se cuenta por la Mancha (y por conocedores de la historia desconocidos, así como, quizá también, por parte del traductor morisco aljamiado, entre otros [o, quizá mejor, en exclusiva]) que Cide Hamete (el cronista árabe que compuso el "original" de la historia de don Quijote -que, traducida por el citado morisco aljamiado y editada por ese segundo autor o segundo narrador mencionado, llegaba al lector en la segunda Parte de la novela-) fingió al comienzo de un nuevo apartado o capítulo de su propia Historia o relación (el "propio original" que se menciona en el texto) - como el mismo Cervantes simulara, por su parte, tras componer el Quijote desde el capítulo IX de la Primera parte-65 que había utilizado un traductor -a su completo y personal servicio- en la composición de su obra (para verter lo escrito por él al árabe clásico, seguramente -la versión que, supuestamente, traduciría al castellano el morisco aljamiado en Toledo-, desde una lengua, o dialecto, como el 'árabe peninsular', la aljamía que utilizaban los moriscos hispanos en España durante los siglos de Oro -más probablemente-66 o el propio castellano) que había trabajado codo con codo con él y que, finalmente, no había sido fiel a su texto al traducir el comienzo de II, 44, pues lo había cambiado a su antojo; y que esto -supuestamente, no se olvide- lo había inventado el propio Benengeli, quejoso "de sí mismo", como excurso por lo

\footnotetext{
${ }^{65}$ Cf. I. Lerner (op. cit., p. 444), quien, a propósito de I, 9, señala cómo "es el narrador el que se apropia de las fórmulas [literario-caballerescas] de sus personajes para descategorizarlas y jugar humorísticamente con los hechos de las ficciones que han enloquecido al protagonista (quedando, así, en entredicho su seriedad y al descubierto su falta de rigor)". Véanse M. Menéndez Pelayo (Orígenes de la novela, I, Santander, Editora Nacional, 1943, pp. 436-37), F. Márquez Villanueva (Fuentes literarias cervantinas, Madrid, Gredos, 1973, pp. 247 y 248-49), M. Socrate (op. cit., p. 34), H. Percas de Ponseti (op. cit., I, 84-85), S. Fernández Mosquera (op. cit., p. 61), J. M. a Paz Gago (op. cit. en n. 6, pp. 30-31), E. C. Riley (op. cit. en n. 30, p. 53) y F. Rico (op. cit. en n. 10, pp. 452-53) para diversos comentarios sobre la simulación de traducciones en los libros de caballerías y la parodia del recurso en su novela por parte de Cervantes. Todavía puede verse utilizado un recurso lejanamente similar al del Quijote, aunque menos rico y complejo, en el Persiles, libr. II, cap. 1. ${ }^{66}$ Cf. Á. Galmés de Fuentes, op. cit., pp. 21 y 38.
} 
"seca" y "limitada" que resultaba la "historia" de don Quijote y Sancho de la que se ocupaba (que tenía "entre manos")' —como ya mostrara el propio Cervantes en el 'Prólogo' de 1605 (pp. 9 y 11)-; y esto había ocurrido así por "lo difícil que le resulta[ba] atenerse en su narración a los sucesos relacionados con la historia principal" 67 al tiempo que dejaba de lado "los cuentos y episodios della, que en parte no son menos agradables y artificiosos y verdaderos que la misma historia" (Quijote, I, 28 [p. 317]), tan propios de la Primera parte de la novela, y como forma, quizá también, de hacerla más entretenida y amena de componer, como de inmediato se destaca en la continuación del inicio del capítulo del Quijote de 1615 de que aquí trato:

y decía que el ir siempre atenido el entendimiento, la mano y la pluma a escribir de un solo sujeto y hablar por las bocas de pocas personas era un trabajo incomportable, cuyo fruto no redundaba en el de su autor, y que por huir deste inconveniente había usado en la primera parte del artificio de algunas novelas, como fueron la del Curioso impertinente y la del Capitán cautivo, que están como separadas de la historia, puesto que las demás que allí se cuentan son casos sucedidos al mismo don Quijote, que no podían dejar de escribirse (II, 44 [pp. 979-980]).

No era este, sin embargo, el motivo final que le movía a actuar en su obra a Cervantes - una vez más bien consciente de los recursos narrativos que utilizaba68 y gustaba de revelar (cf. Spitzer, op. cit., p. 186)-. Pero poco importaba, pues se dotaba, así, a la obra de un aparente nuevo intermediario y de otro plano más, aunque fuera fingido y de muy pequeño alcance, que se burlaba, en último término, de la ya bastante amplia nómina de narradores, componedores, revisadores, editores, comentadores y traductores de la supuesta historia real, verídica, de don Quijote que hasta ese momento habían sido utilizados en las dos partes de la novela y que explicaba uno de los aspectos y artificios - el de la unidad de la obra (vid. Riley, op. cit. en n. 1, pp. 33 y 40]) - más criticados de la Primera parte del Quijote -o que ya no satisfacía a su autor por esos años, por lo fácil y lo alejado de la normativa aristotélica, tan de su gusto, que resultaba la intercalación de novelas o narraciones que nada tenían que ver con la historia central-. De ahí que fuera variado en la Segunda:

${ }^{67}$ M. Joly, 'Comentario a capítulo 44', en F. Rico (dir.), op. cit. en n. 2, II, p. 185.

${ }^{68}$ Cf. J. M. ${ }^{a}$ Paz Gago, "Texto y paratexto en el Quijote”, en M. García Martín et alii (eds.), op. cit., II, [pp. 761-68], pp. 764 y 767. 
Y, así, en esta segunda parte no quiso ingerir novelas sueltas ni pegadizas, sino algunos episodios que lo pareciesen, nacidos de los mesmos sucesos que la verdad ofrece, y aun estos limitadamente y con solas las palabras que bastan a declararlos (II, 44 [p. 980]). ${ }^{69}$

7. De todo lo anterior se deducen algunas conclusiones, que podrían parecer exageradas o magnificadas si no fuera por que parece evidente, por un lado, que "es privilegio de libros como el Quijote que contengan mucho más de lo que el autor haya querido poner en ellos" (E. C. Riley, op. cit. en n. 1, p. 71), así como que, por otro -y según señalara L. Spitzer (op. cit., p. 137)-,

Cualquier aspecto periférico, si seguimos su pista atentamente hasta el centro, nos permite echar una mirada al interior del conjunto artístico, cuya unidad, de este modo, habrá sido respetada.

De ahí que pueda verse en el inicio de II, 44 cómo Cervantes ampliaba una vez más la posible temática de su narración con un aspecto o asunto relativamente novedoso en el momento, "l'auteur et son oeuvre", que se convierten, así, en personajes ${ }^{70}$. Asimismo, se advierte en el fragmento cómo se utilizaba la figura de Cide Hamete Benengeli, en el Quijote II, para interrumpir el hilo de la historia - en este caso, tratando al comienzo de capítulo de algún aspecto relativamente alejado de los hechos de don Quijote y Sancho- (véase s.).

Intentaba también Cervantes con el pasaje aumentar la sensación de ilusión y verdad históricas —que parece conseguirse en la obra con los autores ficticios, el supuesto verdadero autor, las fuentes...-, su verosimilitud, ${ }^{71}$ así como "la apariencia de que el personaje [esto es, Cide Hamete Benengeli] tiene autonomía completa" y una existencia real "independiente" de la que la novela le presenta al lector ${ }^{72}$ - hasta el punto de que mostraba, supuestamente, la "independencia de la mente humana y de un tipo de hombre particularmente poderoso: el artista" (L. Spitzer, op. cit., p. 178])—; asimismo, se conseguía destruir, una vez más en la obra, la separación clara entre lo real y lo imaginario, entre lo ficticio y lo histórico, entre lo verdadero y lo falso, ${ }^{73}$ al

69 Véase, también, Quijote II, 3 [p. 652], así como H. Percas de Ponseti (op. cit., I, p. 168).

${ }^{70}$ S. Bencheneb y C. Marcilly, "Qui était Cide Hamete Benengeli?", en Mélanges á la mémoire de Jean Sarrailh, I, Paris, CRLIE, 1966, [pp. 97-116], p. 104.

${ }^{71}$ Cf. B. W. Wardropper ("Don Quixote: story or history?", Modern Philology, LXIII, 1 (1965), 1-11, p. 5b) y J. M. Martín Morán (op. cit. en n. 17, pp. 148-49).

72 R. S. El Saffar (op. cit., pp. 298 y 299, respectivamente); cf. R. L. Predmore (El mundo del «Quijote», Madrid, Ínsula, 1958, pp. 18-19), E. C. Riley (op. cit. en n. 1, pp. 71-72 y 76), J. M. Martín Morán (op. cit. en n. 17, p. 149)... De ese modo, recuperaba "una buena parte de su perdido estatuto de realidad, acercándose un poco más al segundo autor", según J. M. Martín Morán (ibid., p. 181).

${ }^{73}$ Cf. B. W. Wardropper (op. cit., p. 6) y J. M. Martín Morán (op. cit. en n. 17, pp. 145-46). 
De versiones y autores ficticios en El Quijote: a vueltas con el ...

tiempo que se distanciaba el propio autor de su creación -introduciendo, a través de los distintos filtros ('autores', narradores, puntos de vista...) que manipulan la historia de los sucesos relacionados con don Quijote, una conciencia crítica en el seno mismo de su creación-74; multiplicaba, una vez más, las voces narrativas - siquiera brevemente, de forma ficticia y en aparente contradicción con alguna otra de las características señaladas- y los diversos puntos de vista y perspectivas que presentaba en su relato, ${ }^{75}$ intentando "recalcar el aspecto ficcional" del mismo ${ }^{76}$ y dejando traslucir esa ironía típicamente cervantina77; destacaba cómo era Cide Hamete "un cronista no fidedigno" que tendía a convertirse en autor de ficciones "algo poeta" (G. Haley, op. cit. en n. 22, pp. 270-71]) -o, mejor, novelista (hasta el punto de inventarse él mismo, per se, los hechos o aspectos que presentaba, como si de una persona y autor reales se tratara [v. s.])-y, por tanto, se le desacreditaba, una vez más, ${ }^{78}$ atacándose así, de nuevo, la supuesta superioridad de la historia y de los historiadores sobre la creación literaria y los autores que se ocupaban de ella (poetas o, como aquí, novelistas). ${ }^{79}$ Se mostraba, además, el autor real consciente de las técnicas que usaba - esto es, pleno de "autoconciencia" (Riley, op. cit. en n. 30, p. 151) - y capaz de jugar con ellas en su obra (la invención de traductores y autores ficticios), que entonces, como "El recurso trillado del manuscrito hallado por casualidad" de que habla J. A. Parr (op. cit. en n. 8, p. 49), resulta "un truco desfamiliarizador que incrementa la ironía postromántica de un texto que hace gala de su artificio, desnudando sus recursos".

Se deja sentir así, una vez más, cómo el uso -inicialmente paródico- de Cide Hamete Benengeli por parte de Cervantes "consigue aumentar la ya notable profundidad del libro" (Riley, op. cit. en n. 1, p. 317) y, cómo en manos de Cervantes, "un antiguo artificio de la prosa narrativa ofrece posibilidades inesperadas" (ibid.). Uno más entre muchos. El juego de planos y simulaciones del alcalaíno parecía no tener límites y moverse en todas las direcciones posibles e (in)imaginables -incluso al comentar y explicar su propio trabajo de novelista, en los casos arriba citados y en otros de la obra, como el error de un "cronista" equivocadamente "convertido en creador" de la novela ya desde la Primera parte del Quijote ${ }^{80}$, pues la verosimilitud, la coherencia interna y la apariencia de

74 Cf. E. Cros (op. cit., pp. 233, 237 y 239), así como R. S. El Saffar (op. cit., p. 293, y Distance and Control in Don Quijote. A Study in Narrative Technique, Chapel Hill, North Caroline Studies in the Romance Languages and Literatures, 1975, p. 123) y H. Percas de Ponseti (op. cit., I, pp. 89 y 103).

${ }^{75}$ Cf. E. C. Riley (op. cit. en n. 1, pp. 71-72).

${ }^{76}$ F. de Toro (op. cit., p. 640); cf. E. C. Riley (op. cit. en n. 30, p. 211).

${ }_{77}$ Cf. F. Rico (dir.) (op. cit. en n. 2, I, p. 48, n. 35) y J. M. Martín Morán (op. cit. en n. 17, pp. 145-46).

${ }^{78}$ Cf. C. I. Neupalsing (op. cit., p. 516).

${ }^{79}$ Cf. B. W. Wardropper (op. cit., passim), así como F. Márquez Villanueva (op. cit., p. 241).

${ }^{80}$ H. Percas de Ponseti, op. cit., I, p. 99; cf. B. W. Wardropper, op. cit., p. 6a. 
verdad histórica de las narraciones habían de quedar muy por encima de la diversión, la variedad o las muestras de ingenio en la Segunda parte-. Se conseguía conformar, así, un relato lo suficientemente autocrítico y ambiguo -dos de las funciones básicas desempeñadas por Cide Hamete-81 para que en ocasiones como esta del comienzo de II, 44 de que me he ocupado aquí la crítica no haya conseguido ponerse de acuerdo en su sentido último (o en si, tan siquiera, lo pueda tener o no).

81 Cf. J. M. Martín Morán, op. cit., p. 145. 